\title{
Roma in Special Education: \\ Discriminating, Segregating, and Limiting Opportunities to Roma Students by Placing Them in Special Schools
}

\author{
Maria Roth ${ }^{1}$, Lorena Văetişi $^{1}{ }^{*}$ \\ ${ }^{1}$ Babeş-Bolyai University of Cluj-Napoca, Faculty of Sociology and Social Work, 12821 Decembrie 1989 Bld., 400604 Cluj-Napoca, \\ Romania
}

KEYWORDS

Roma

Special education

Discrimination

Segregation

\section{A BSTRACT}

In social and educational practices, a number of 'negative' descriptive categories such as minority or disability determines inequalities and deepens the vulnerability of such groups. We focus on the Roma students enrolled in Special Education and analyse the mechanisms of (re)producing stereotypes and discrimination. We interpret qualitative research data, conducted in a technical high-school from Cluj-Napoca. Our study concludes that Roma schoolchildren enrolled in special education, whether or not really disabled are discriminated against (on behalf of an educational practice that reinforces the stigma of an inferior ethnic group, socio-culturally marginalized) and thus, their opportunities are severely limited, since their very youthful years, spent in school education.

\section{Introduction}

In this article we study how educational practices, having as descriptive categories ethnic minority, impairment, disability and low socio-economic status lead to reproducing inequalities and deepening the vulnerability of the groups described as such. In our research, we have considered the Roma students enrolled in special education under the name of 'cerințe educative speciale' (CES, i.e. students with special needs). We discuss how these students ended to be enrolled under this category and how this restricts their potential for educational and social integration possibilities, limiting

\footnotetext{
*Contact addresses: roth.mari@ymail.com (M. Roth), lorenavaetisi@yahoo.com (L. Văetişi)
} 
their career opportunities, thereby reinforcing their status as a vulnerable group, characterized by poor school training, marginalization and poverty.

The analysis uses the concept of intersectionality to capture the mechanisms of (re-)producing stereotypes and discrimination in populations, who suffer multiple forms of discrimination (as ethnic minority, mental disability, gender, etc.) and interprets data obtained from a qualitative research, conducted in a technical school from Cluj-Napoca (Grupul Școlar S.). Throughout our analysis we also refer to various statistical data, legislation and educational policies aimed at minority groups, particularly Roma.

\section{Minority students in special education}

A series of researches conducted in the U.S. and Europe, the early 1960s, have shown into the focus that minority students are over-represented in special schools (Artiles 1998; National Research Council 2002; Harry and Klinger 2006). Possible explanations to this tendency are given by Oswald, Coutinho and Best (2002), who notice that, on the one hand, minority students are more likely to develop disabilities, because of the unfavourable physical, social and educational environments they live in, and, on the other hand, because they frequently suffer from inadequate assessments of their ethnic and cultural differences.

The practice of segregating Roma students by selective enrolment in special schools has been happening in Central and Eastern Europe countries, since the 1990s. For example, in Serbia, in 2008-2009, from the total number of students enrolled in special education (with intellectual disabilities), about $30 \%$ were Roma, whereas Roma represented only $6 \%$ of the population in Serbia (Open Society Institute 2010). According to the same study, data appear to be even more alarming for the Czech Republic. In Romania, the segregation of Roma students in special classes/schools is a common practice. In some localities, in special education, up to $70 \%$ per cent of the student population is Roma (see below).

Special education in Romania is part of the public education system and it is administered by the Ministry of Education (The Ministry of Education, Research, Youth and Sport) and, locally, by the county school inspectorate 
and the local government. It has parallel structures to mainstream education, namely, within the pre-university education. Special education has a complex network of schools/special classes, at primary and secondary levels, as well as Schools of Arts and Crafts ${ }^{1}$, which are also accessible to students with CES. Special schools do not provide the same educational opportunities as mainstream education. For example, students with CES do not take the national tests, which are mandatory at the end of the eighth grade, and therefore they cannot enrol in high school. The only chance for them are 'sscolile profesionale' (apprentice schools), that can be graduated after two years, by getting a professional qualification (level 1), with the possibility of completing an additional year, to achieve level 2 .

In recent years, a number of regulations on minority education were adopted, some having general applications for all minorities, others being aimed only at Roma students. Among these, one of the most important is Law no. 48/2002, for the approval of the Government Ordinance no. 137, which stipulates that denying access to a person or a group of people to any level and form of education, due to its membership to a specific race, nationality, ethnicity, religion, social category, or disadvantaged category is a punishable offence. In addition, the Notification no. 29323 from 2004, issued by the Ministry of Education and Research, prohibits any form of segregation, within high school education. This notification explicitly prohibits segregation of Roma children in schools.

Regarding the educational programs that target vulnerable groups (such as Roma children) among the most important are the 'Access to Education for Disadvantaged Groups' (PHARE 2004 and 2005) or the 'Second Chance' (MEN Order no. 4231/1999). The latter provides support for those who have left school and want to continue studies in order to pass the baccalaureate exam and/or to attend apprentice schools. Within this program, educational institutions, NGOs, and the local administration are all involved.

The number of Roma students enrolled in special education can only be estimated. Human rights activists reported that in the case of special schools, the percentage of Roma children is as much as $70 \%$. However, for 2007 there was no solid research to assess accurately the over-representation

${ }_{1}$ According to the Ministry of Education, the Schools of Arts and Crafts are equivalent to apprentice schools. 
of Roma children in special schools (Roma Education Fund 2007). We are not aware of more recent studies relating to this topic. ${ }^{2}$

\section{Assessing students with disabilities}

In Romania, students with various types of disabilities (mental, physical, hearing and visual impairments or behavioural, etc.) are orientated towards special schools. Also, students who repeat the class in normal schools at least twice are evaluated by a committee that uses complex psychological tests, in order to assess their intellectual capacities, after which, in most cases, they are sent to special schools. A 2005 report of the Open Society Institute noted that:

'According to some psychologists, the evaluation of children is often superficial, as the examining psychologists lack standardized instruments and tools. They have developed and produced their own testing methodologies. There is no special training for doing such evaluations, as there is no specific instruction on assessment techniques available' (Open Society Institute 2005: 36).

Along with this critical issue, the same report noted the large number of Roma students who are guided toward special schools, on the basis of the 'intellectual disability' diagnosis as well as their problem of confronting a double discrimination. 'Intellectual disability' is only one type of disability accepted by special schools; other similar assessments guide Roma students to the same type of school because of other disabilities:

'NGOs have noted that a disproportionately high number of Roma children are diagnosed with intellectual disabilities and that, in some cases, up to 70 per cent of the students in special schools are Roma. Roma with intellectual disabilities are at a special disadvantage, as they may face dual discrimination on the basis of both disability and ethnicity' (Open Society Institute 2005: 37-38).

In general, testing intellectual skills is done by tests validated on the majority of population, which tends to disregard cultural, ethnic or gender differences (this aspect, regarding the criteria for testing, is subject to a rich bibliography in the U.S., African-Americans, criteria considered to be

\footnotetext{
2 For older estimations of the number of Roma students in some special schools, see European Roma Rights Centre 2001: 64 and Liga Pro Europa 2006.
} 
formulated in the terms of the white man, seen as normative 3 ). As a critical effect, minority families, for example, in the case of Romania, Roma families, tend to agree (although they may deny it), that their sons and daughters attend special schools, because 'that has been scientifically established'.

\section{Studies in Roma Special Education in Romania}

There is yet another aspect. Due to the socio-economic situation in which the majority of these families live, they do not realize that, in time, the placement of their children in special school limits their educational opportunities, and their future lives. This occurs because these families focus mainly on the immediate minor benefits provided by enrolling their children in this type of education, as long as students in special schools are offered a free daily meal, school supplies and other facilities. For poor Roma families, these advantages are more important that thinking about the future benefits education could bring4.

A study of the inclusion and exclusion of Roma in present-day Romania (Florea and Rughiniş 2008) presents some analyses of the Roma communities and schools in Cluj. The research conducted in one of the most disadvantaged Roma communities in Cluj (the Byron street community), highlighted:

'(...) an important phenomenon, which is partly the result of formal failures in the educational system: the registration of Roma children in special schools (schools for children with special needs), although they are not mentally challenged' (Florea and Rughiniș 2008: 156).

The formal failures in the educational system are the second major cause of the large number of Roma students in special school.

The 2007 Open Society Institute report on Equal Access to Quality Education for Roma mentions in Section no. 4:

\footnotetext{
3 This is one of the central themes of the critical race theory, as an attempt to deconstruct the 'white privilege', according to which the social and political norms and forms (including education) are built on the model of a 'white' (and male) ideal-type. See for example Shapiro 2004 and Dixson and Rousseau 2006.

4 See a discussion on this aspect in Vincze and Harbula 2011, especially pp. 33-102.
} 
'The main barriers which limit Roma children to fully access education are, among others, the impact of segregation, either in schools serving exclusively Roma neighbourhoods or villages, in separate classes within normal schools, or in special schools, for people with intellectual disabilities' (Open Society Institute 2007: 8).

There are highlighted again, the mental disability as a category to which Roma children are part of, as well as their segregation and limitation to educational opportunities. It is explicitly mentioned the possibility of Roma families to choose the normal educational system, as well as the modalities of limiting these options:

'Legally, parents may choose any school from the system, regardless their domicile. However, some informal agreements of the Inspectorate restrain the free choice of parents to a specific school that they want their children to attend. Frequently, the headmaster takes the decision to allow a child to be enrolled in his school. If the headmaster does not accept the parents' request, parents may go to the Inspectorate and, if not successful, to the Ministry. The children's evaluation for being enrolled in special schools is initiated either by the child's parents, or by the school. The Department for Complex Evaluation (Serviciul de evaluare complexă) assesses and determines the diagnosis of children with disabilities. This department is part of the County Directorate for Social Worker and Child Protection. Before a child is being enrolled in special education, he is evaluated by a set-up multidisciplinary expertise committee (a psychologist, a psychologist-pedagogue, a medical doctor and a social worker). After the evaluation procedure, the level of disability is established and the file is submitted to the Commission for Child Protection, which issues a Decision, a certificate for the degree of disability, a certificate for school, a professional reorientation, and a rehabilitation plan' (Open Society Institute 2007: 407-408).

Some other disfunctionalities and possible motivations for Roma families' choices to a specific type of education are also mentioned:

'At present, there are no Roma (or other ethnic minorities) representatives within the commissions (...). Concerns of the overrepresentation of Roma in Romania's special education system have been acknowledged in the past. Reasons such as free meals and housing for children of disadvantaged families, including Roma are generally cited. According to a representative of the Ministry of Education and Research, until 2000 quite a high number 
of Roma students were enrolled in special education, due to the social services available there (meals, school supplies, accommodation, therapy, clothes); these students were regarded as «lacking the necessary cognitive skills and behavioural adaptation needed for school integration». Since 2000, diagnosis of disability has been a prerequisite for the enrolment in special education. A written report by a Phare project (2003) noted the following: «Many students in special schools appeared to be there for social reasons. Children with severe special needs often do not attend school at all.»' (Open Society Institute 2007: 409-410).

\section{Grupul Școlar S: How are Roma and Roma students perceived in special education?}

\section{Introducing the school and the research}

Grupul Școlar S, a remarkable technical school, located in Cluj city, in a working-class neighbourhood, trains students for socio-professional integration. ${ }^{5}$ At the beginning, the school addressed to students with hearing disabilities, and later on, also mental ones. In 2006, it became an inclusive school, with normal and special education classes.

Students' families and their social environment are generally disadvantaged (many poor families, many children in a family, single parents, parents with no interest in their children's behaviour and school performance). A significant number of students came from orphanages and care centres.

We conducted a qualitative research, as part of a larger one, which also shows into the focus ethnicity and gender in education. These descriptive categories, such as socio-cultural dimensions influence school environment, school attendance, school perception, school and professional success. Within the research, we interviewed 22 students, girls and boys in grades 9 and $10^{\text {th }}$, of Romanian and Roma ethnic backgrounds, enrolled in normal and special schools, in the following technical/apprentice school types: Hairdressing-Manicure-Pedicure, Hairstyling, Woodworking and Locksmith-Tinsmith, as well as three teachers, including the headmaster. We

5 'Grup Şcolar' is a title for a technical school, i.e. a form of education percieved as inferior to 'liceu' (high school). 
intended to understand the references related to Roma ethnicity and disability, from the perspective of those involved. Bellow, there are some fragments of the interviews, which we contextualized and further interpreted in the terms of the aspects considered so far.

\section{Differences, ethnic issues, cultural models, stereotypes, educational opportunities}

Most of the 22 students interviewed do not consider Roma ethnicity being different. They believe that it's not the ethnicity, but the behaviour and 'the respect that someone shows' that matters:

I respect them as anyone else and I consider Roma mates as being my friends... the ethnicity doesn't matter... (CDV, Romanian student, 18 years)

Roma students are just like us, I have no problem [with them]. (LE, Romanian student, 16 years)

Generally, I have a good opinion of Roma students, but not always. A good one, when I understand with them and a bad one when I am fighting with them. (MD, Romanian student, 15 years)

I don't have problems with my Roma classmates, we are all colleagues. (SB, Romanian student, 17 years)

However, there are students, who blame Roma for having a different (negative) behaviour, whether it is noticed or experienced. Others claim that their own behaviour is negatively influenced by the Roma students; they suggest segregation as a solution, negative stereotypes related to this ethnic group being reinforced.

I would separate the Roma from the others..., I know from the other school [I attended], where there were more Roma, that they had an [negative] influence on you, they "hurt» your mind, you'll behave like them; you start to swear, and things like that, it would be more discipline in the classroom [without them]. (BA, Romanian student, 17 years)

I don't have a good opinion having Roma classmates. They steal, they talk ugly to you. I don't have a good relationship with them. I have about four Roma classmates and all behave badly, they steal... I don't know why they behave like that. (GA, Romanian student, 17 years) 
Many of these ideas and arguments are confirmed in the interviews with teachers. It seems that ethnicity in itself does not matter, but the personal characteristics related to the particular contexts (such as families), perceptions (based on stereotypes) and the personal, direct relationship they have with the Roma students:

Roma students are like others, depending on their individuality and family backgrounds, whether they show respect or not... sometimes you get along with them, better than with the Romanian students... (VC, MasterTrainer, Carpentry)

The poor socio-economic conditions, housing and food problems, the existence of large families, low incomes, the parents' educational levels, and not always having access to educational opportunities are, generally, associated with Roma students, as a vulnerable social group. Some educators admit that Roma have specific problems, particularly economic, social and cultural ones:

There are particular problems of Roma students, which are related to the social environment they live in. We talk about a socially disadvantaged environment, with very poor housing conditions, large families... We have two areas where almost all these students come from: Cojocna and Pata Rât... In the history of our school, there were children who saw a shower for the first time in their life, only here, in our school... What could you expect from such children? How did they grow if they hadn't seen a shower?... But they get used to it and by education, including, let's say, non-formal education, although it should be formal... we insist on familiarizing them with these [civilized] habits... We don't have quantifiable data... but from talks with other colleagues we notice a significant progress, especially in middle school. (AC, headmaster)

In the case of Roma students, some teachers consider that adaptation to school is quite difficult, especially related to the appropriate manners and communicating behaviour. They claim that these difficulties often generate behavioural problems, as well as disinterest in attending classes:

They come to us after a period of at least 4-5 years [spent] in other schools; now we have enrolled some Roma students from the Cojocna area, in the 5 th grade, ${ }^{6}$ who do not respect any rule. They don't know they have to sit down at their desks, to come to classes, to speak only when they are asked, and it's very hard for us at the beginning, until we "form» them. It's

\footnotetext{
${ }^{6}$ Cojocna is a commune in the outskirts of Cluj city, with a significant number of poor Roma families (according to the 2002 census as much as 19.5\% were Roma in Cojocna, compared to $2.5 \%$ at national level).
} 
normal... they weren't familiarized [with these rules], that's the big problem... As far as I understand, their big problem is they are continuously missing school. (AC, Headmaster)

Many Roma children attend special education, as in the past they failed in the mainstream school and they have to repeat the grade. After two or three repeated grades, they are sent to special schools, not necessarily because they have intellectual disabilities, but because it is considered they aren't able to attend the mainstream education:

There are some who don't have intellectual disabilities, but they didn't attend [school], and they repeated the grade twice or three times, and then, they are sent to us. Personally, I think that it is a chance for these children to learn a trade... We provide them certain facilities. (AC, headmaster)

Specific cultural practices, the lack of rules, or the family models which are distinct from the majority's ones have a deep impact on the Roma students' behaviour in school, and on how they are perceived by their classmates and instructors:

(...) One can notice the lack or bad influence the family has on their children; I mean, the families don't teach them the minimum rules of behaviour and their children are not used in practicing any kind of rules. (AC, headmaster)

The Roma traditional cultural models consider the man (husband) as a breadwinner. This mentality restricts the girl's professional options and their opportunities to have a career. Many of them do not realize the importance of the academic/professional success and the financial independence they could get by having a career after graduating. They lack motivation and they are influenced by their friends belonging to the same ethnic group, who considers that preserving their tradition is the best for them:

In my class, the Roma schoolgirls don't want to work... They don't... They argue that «my mother doesn't work, so neither I». They want to continue the same model seen in their families: «my husband has to work for me». The twin girls don't want [to work]... I offered them the opportunity to enrol in the second level, but they don't want to learn a trade. "We don't want... our boyfriends will work for us, they won't let us work»... This is their tradition, they say so... They were enrolled because they were distributed in this apprentice school (i.e. at the Hairdressing-manicurepedicure). They are normal students but I don't think they will be able to integrate into the labour market because they are not motivated by friends or families, no matter how well they are professionally trained... at least 
regarding the first level. They have my support for a successful job... I even suggested them to go to visit a hairdresser lady, who invited them to her salon, to watch first. The Roma schoolgirls refused to go there. "We'll never work, it's worthless». They came here to graduate the school, and that's all. (MA, Master Trainer, Hairdressing Department)

The different views on educational and professional trainings, that appear even in the intra-group level among Roma schoolgirls, show that the reference to ethnicity and cultural traditions depend very much on whether they belong to the so-called Roma 'traditionalists' or to the 'civilized', or 'more Romanians' ones, as they identify themselves with.

Many Roma students consider that they are not discriminated against in schools, either by their teachers, or by their peers. However, the way they are perceived and described suggests discrimination. Although in recent years, many negative aspects regarding their treatment have been eliminated, there are still many issues, ranging from administrative problems to accessing information, that affect them. For example, some of them have no identity papers, even if they are 15 years old. But other Roma benefit from the opportunity to go to school on the places registered only for Roma students. These ones are more informed and they invalidate the traditional models (including the gendered ones). To go to high school / technical school is a matter of pride for them:

I am Roma too... Ethnicity doesn't matter; I have Romanian and Roma friends, friends from Italy... I came up [to school] on the places reserved for Roma students in the hairdressing [department], a very good opportunity for me to have a good job, I am proud of it ... (VL, Roma schoolgirl, age 16)

While some Roma students assume their ethnic background, others do not. But all of them assumed that what it matters it's the behaviour and the respect showed to the others and not the ethnicity. However, as we have seen, the behaviour itself has an ethnic connotation. On the other hand, there are differences within the Roma ethnic group:

I am a Roma too, and I'm proud of it...I am respected by my schoolmates, so it doesn't matter if you are Roma or whatever; we are all humans. We are different from other Gypsies; we don't talk «corturăreşte» (i.e. like the nomadic Roma); we are as civilized as people generally are. We speak Romanian and Romany too, but not Hungarian...There was no injustice of me. They are all my friends. I respect them and they respect me, regardless of being a Roma or not... When I am with my mates who speak 
only Romanian, I don't speak Romany; I only swear in Romany behind their back; I speak calmly in their language. We speak Romany and Romanian at home; my parents speak Romany more; sometimes I forget Romany... (SV, Roma schoolboy, 16 years)

Regarding the stereotypes associated with Roma as being dirty, poor, and uneducated, it has to be mentioned that these qualifications are also present in other communities. The Roma students try to counter these stereotypes, by giving examples of success from their own ethnic group:

I have a worse opinion of other colleagues, rather than of the Roma ones, and I can admit I am a Roma, I don't hide it. I feel that I get along better with boys of my ethnic group... I don't know... they think like me, they have the same thoughts There are things that offend me - a kid looked at me on the street and said: «look mum, the Gypsy», and I felt embarrassed; it would be in vain to explain them that I am not a Gypsy of that kind... people judge you too much... including the way you dress... I don't want to accuse anybody, but I saw in the countryside... there are Roma who own big houses, and the Romanian peasants, I don't want to offend them, have nothing, they are poorer than Roma... and if you tell them so, they say that Roma got the houses by begging and stealing... but, there are Roma who are clever and quick in action;... just take a look at the 'manele' musicians. (SI, Roma schoolboy, age 18)

\section{Understanding the intersections of inequalities in education and the vulnerability of Roma students}

Grupul S,colar S. is a technical school that provides both normal and special education (for students with special needs). From this point of view, this school apparently doesn't seem to be a segregating place; nevertheless the policy of 'integration' does not bring the expected results7. The curriculum standards are distinct from the main stream education. The students with special needs do not have specific standards, such as the acquisition of a minimum level of knowledge and skills, as in normal schools. The basic rule is that the educational process is guided by the students' individual learning

\footnotetext{
7 Since 2004, school legislation favoured the integration of children from special schools into mainstream schools. These changes were mainly related to EU accession requirements. Based on these regulations, students with intellectual disabilities were integrated into mainstream schools, but according to Equal Access to Quality Education for Roma report (Open Society Institute 2007: 94), their school career is limited monitored. In addition, as discussed above, they are subjects to new (or enhanced) discrimination, segregation and opportunity limitations.
} 
possibilities. Thus, the students with special needs are individually assessed, have customized intervention plans, with different levels of training and performing, so as to pass the class (Open Society Institute 2007: 109). These formal aspects are determined by the daily educational process and suggest special circumstances (i.e. the students are enrolled in a special education program). In the case of Roma students it deepens the segregating practices and the stereotypes they are associated with.

Segregating and negatively stereotyping, in association with ethnicity and socio-economic disadvantages, are evidentially exemplified in the above interviews. Roma students' progress is generally related to the 'civilizing' challenges. The negative aspect is not perceived (as well as it is not perceived the role of cultural differences in the behaviour or attitude towards school), but only the positive one, the 'civilizing' progress: 'I, personally, think that it is a chance for these children to learn a trade... we provide them certain facilities', related a teacher, without noticing that this implies the idea of a 'negative difference' and the stigma of 'deficiency' added to the already a negative one, Roma ethnic identification.

Adopting a 'civilizing discourse', ('we are civilized', says a Roma student, in order to distinguish himself from other Roma) confirms an insidious discourse, that it is internalized by those discriminated against. This is reinforced by the agglomeration of 'negative' descriptive categories (such as Roma, disabled, poor, sometimes girl) and the ways in which depending on the context, the Roma identity is assumed or rejected by selecting some of the descriptive categories, in dual linguistic practices (Romany and Romanian language) or dual self-identification (Roma/Romanian).

Very few students succeed to get a job and to be reasonably paid, said a master trainer, although according to legislation, companies may benefit if hire students from special education school. 'School here it's not great shakes because it's special education... maybe I can use my elementary diploma from a mainstream school... I realize that I can't do big things after graduating a special school, whatever others might say. It is as if you put a normal person near a mad one... I'll fail if applying, because I graduated a special school...' confessed a schoolgirl. 
If we were to examine the problems these students have, then we should find a variety of aspects which certainly couldn't be included in the category of 'deficient', even if referring to the students' school capacities. There is a large variety of difficult or favourable situations for Roma students: 'administrative' issues (some students do not have papers or permanent residence, in the case of the most disadvantaged ones); others, the most informed, turn their 'problematic' status into an advantage: go to special reserved places for Roma students in high school or university. In the last mentioned situation, it is obvious that the students ignore stigma and they benefit from this advantage. This beneficial advantage is also taken by the girls who reject the domestic status of Roma traditions and go to school for a career.

The trend to counteract the negative image of Roma by providing 'successful models' (also noticed in the media discourse), contains as well some critical issues that are evident in the last fragment of the interview we quoted above. These successful models are seen reluctantly, suggesting that there must to be a 'trick' somewhere, something 'special' that Roma did in order to succeed. This perception of something being 'special' is common for understanding the status of Roma in special education: they tend to be accepted in the educational system (of the 'whites'), only if they are enrolled, labelled, and stigmatized with the status of 'special'.

Accordingly in the above interviews we could detect some types of discourses that characterize the ethnic group as a whole, their status as students of special education, and the discrimination at the discursive level. Thus in our analysis we propose to refer to the following types of discourses: 'labelling discourses' (stigma), 'compassionate discourses' (their condition is pitied), 'discourses of normalization' (their situation is compared to a norm they have to fulfil) or 'civilizing discourse' (overcoming the 'deficiency' and integrating these students being associated to the process of 'civilizing' them). In addition, tracing a parallel between how Roma students characterize themselves (self-identification) and the hetero-identification made by the majority of students, by the students from the mainstream education, as well as by the teachers reveal both different perspectives about Roma students and also segregation, discrimination and limitations of the 
educational opportunities they may experience. The table below is a synthesis of this analysis.

Table 1. Types of discourses about Roma students in special education. Heteroidentifications and self-identifications

\begin{tabular}{|c|c|c|}
\hline & Hetero-identifications & Self-identifications \\
\hline Labelling discourse & $\begin{array}{l}\text { They steal, they speak ugly to me. } \\
\text { (GA, Romanian schoolgirl) } \\
\text { Roma students are like anyone else, } \\
\text { but they use ugly words, especially } \\
\text { at school and on the streets and they } \\
\text { behave badly, they kick over the } \\
\text { traces, they hit you, they spit, they } \\
\text { steal you. (BA, Romanian } \\
\text { schoolgirl) }\end{array}$ & $\begin{array}{l}\text { I am Roma too, and I'm proud of it. } \\
\text { (SV, Roma schoolboy) } \\
\text { It would be in vain to explain them } \\
\text { that I am not that kind of Gypsy. } \\
\text { (SI, Roma schoolboy) }\end{array}$ \\
\hline $\begin{array}{l}\text { Compassionate } \\
\text { discourse }\end{array}$ & $\begin{array}{l}\text { I don't think they would be able to } \\
\text { integrate into the labour market } \\
\text { because they are not motivated by } \\
\text { friends or families, no matter how } \\
\text { well they are professionally trained. } \\
\text { (MA, master trainer) }\end{array}$ & $\begin{array}{l}\text { So, I don't know what to say... I feel } \\
\text { equal, like a normal child... (VL, } \\
\text { Roma schoolgirl) }\end{array}$ \\
\hline $\begin{array}{l}\text { Discourse of } \\
\text { normalization }\end{array}$ & $\begin{array}{l}\text { They don't know they have to sit } \\
\text { down at their desks... it's very hard } \\
\text { for us at the beginning, until we } \\
\text { «form» them. (AC, school } \\
\text { principal) }\end{array}$ & $\begin{array}{l}\text { I came up to the school on the places } \\
\text { reserved for Roma, in the } \\
\text { hairdressing department, a very } \\
\text { good opportunity for me to have a } \\
\text { good job, and I am proud of it... } \\
\text { (VL, Roma schoolgirl) }\end{array}$ \\
\hline $\begin{array}{l}\text { Civilizing } \\
\text { discourse }\end{array}$ & $\begin{array}{l}\text { In the history of our school, we have } \\
\text { children who saw a shower, only } \\
\text { here in our school...for the first } \\
\text { time in their life. I personally, think } \\
\text { that it is a chance for these children } \\
\text { to learn a trade... we provide them } \\
\text { certain facilities. } \\
\text { (AC, headmaster) }\end{array}$ & $\begin{array}{l}\text { We don't talk 'corturăreşte', we are } \\
\text { civilized people. } \\
\text { (SV, Roma schoolboy) }\end{array}$ \\
\hline
\end{tabular}

\section{Conclusions}

The 'reasons' for placing Roma students in special schools are not transparent or very clear. Placing Roma students in special school might be regarded as a vicious circle. Although this placement is supported by formal and legal expressions, the orientation to special education being the result of an assessment, there are many questions related to the testing techniques 
and diagnosis of the impairment/disability of a student with learning difficulties, disciplinary problems or school failure ${ }^{8}$.

For example, in the psychological evaluation sheet, there are such expressions as 'level of intellectual development'. This is important when someone tests the learning difficulties, but it can be interpreted very broadly, related to the diagnosis of the impairment/disability. Obviously it is a subjective or partial procedure, which could lead to the ethnic groups' discrimination, by placing them deliberately or unconsciously, in special education.

Besides these evaluation shortcomings, there is another current situation that leads to placing Roma children in special schools: formal failures in the mainstream schools (where they are initially enrolled), as one of the headmasters recognizes. Hence, it is explicitly acknowledged that many Roma children attend special schools not because of real impairment/disability, but due to school absenteeism and incomplete annual school assessments. This is a vicious circle in which prolonged absence in school is combined with the lack of real interest in attending school. As various studies show (among those already cited: Open Society Institute 2007; Florea and Rughiniş 2008; Vincze and Harbula 2011), in most cases Roma students are constrained by poverty or fluctuating socioeconomic and housing conditions (and often forced by their parents) to being recurrently absent in school. Poverty or family practices limit thus the access to education for Roma children, as they are forced to participate to generating income activities, or to take care for younger siblings (Open Society Institute 2007: 89). This aspect is however far from being eligible to be enrolled in special schools.

Consequently and probably the most critical aspect is that Roma continue to remain a vulnerable group. Additionally, as suggested in my analysis, their vulnerability is amplified by the intersection of several unfavourable characteristics: the Roma ethnicity, the impairment/disability

\footnotetext{
8 The Child Assessment Service was established and operates under art. 20, paragraph 1, of Resolution no. 1205, November 27, 2001. According to this decision: 'The service identifies the children with disabilities, learning difficulties and reduce capacity to socio-educational adaptation, and requires a degree of disability and school/professional orientation (...) The identification of children with disabilities is performed by medical specialists (infantile neuropsychiatry, paediatrics, neonatology, family medicine, etc.) within hospitals, clinics or medical offices, by teachers in mainstream or special education or by the local communities.' 190
} 
they are labelled and stigmatized as (students in special education), the disadvantaged social-economic condition (poverty, no access to some facilities and the lack of normal' or 'civilized' manners and in some cases gender, and even age (see below).

Roma schoolchildren enrolled in special education, whether they have or not have real disabilities, are discriminated against and segregated according to educational practices, even when these practices are assumed to be inclusive (by setting up schools with mixed classes: mainstream and special education). Their stigma of an inferior ethnic group, socio-culturally marginalized is reinforced and consequently their opportunities are severely limited, since their very youthful years spent in school education. Even if in everyday situations, discrimination is not obvious, it might be manifested in more subtle ways, as the report Equal Access to Quality Education for Roma remarks: (OSI, 2007, p. 434):

'Experts reported for the project 'Access to Education for Disadvantaged Groups' (2003) that they did not notice any class in which teachers deliberately discriminated against students, but they were concerned with some prevalent behaviour that was unintentionally exclusive (although paradoxically the teachers probably intended the opposite). For example, some teachers proudly pointed out children in the class as being Roma or as having special needs, meaning to show that the class was inclusive, but in fact drawing unwelcomed attention to children. In many schools, children with disabilities were singled out and given inappropriate attention in front of visitors. For example, children were referred to as having «very severe deficiencies» in front of themselves and their classmates. Many mainstream teachers used the labels that were written on certificates of special educational needs.' (Open Society Institute 2007: 434).

As in the example above, even if segregating practices aren't intended, the attitudes towards Roma students in special education and the labels that are repeated to them, contribute to creating a radically different category, with no opportunity for interacting with the 'normal' majority. This is supported by the discourses which reiterate the attributes of normality and abnormality, negative differences, negative stereotypes, progress seen as a civilizing process, success understood as fraud or exceptionality, etc.

Although in Romania at national level, the over-representation of Roma children in special schools with mentally-disabled students is not a 
worrier as in other countries (Open Society Institute 2007), many Roma children end up in these forms of education, not only because of discriminating and segregating or medical reports, but also because often Roma families choose to send their children to special schools, because they want to take material advantages (such as food, accommodation, etc.). ${ }^{9}$

The Open Society Institute report suggested that these material advantages should be available for any student with disadvantaged backgrounds, and not only for those who attend special education. If this was applied, it would be possible to avoid the enrolment in special schools, if there were no disability reasons. In our research, this suggestion wasn't mentioned. The same report suggests that 'The Second Chance' Governmental Program generally attended by Roma (therefore having a segregationist form) remains a better option than the efforts of integrating students who failed in the mainstream education and are older than their classmates in special schools.

The terminology of these forms of education (impairment, disability, special needs) indicate on one hand medical impairment/disability, negative difference, the deficiency as lack of 'normality', the inability to be like the majority, and on the other hand, the idea of 'dependency'. Segregating and discriminating practices are reinforced by enrolling Roma students in special classes.

\section{Acknowledgement:}

The authors wish to thank for the financial support provided by the Sectoral Operational Program for Human Resources Development 2007-2013, POSDRU Contract No. 6/1.5/S/4 - 'Doctoral Studies, A major factor in the development of socio-economic and humanistic research', for its financial support.

\footnotetext{
9 This aspect is reported by other Eastern European countries. For example, the Bulgarian State Agency of Child Protection (2005: 54) noticed that: '[Roma] parents prefer to place their children in a remedial (i.e. special) school for a number of reasons - boarding services, free textbooks, and free or cheap food'.
} 192 


\section{References:}

Artiles, Alfredo J. 1998. The Dilemma of Difference: Enriching the Disproportionality Discourse with Theory and Context. The Journal of Special Education 32 (1): 32-36.

Dixson, Adrienne D. and Celia K. Rousseau. 2006. Critical Race Theory in Education: All God's Children Got a Song. New York: Routledge.

European Roma Rights Center. 2001. Stare de Impunitate: Incălcarea Drepturilor Omului - Cazul Romilor din România. Country Reports. 4. București: Centrul de Resurse pentru Comunitățile de Romi.

Florea, Ioana and Cosima Rughiniș,. 2008. Education Issues. In Come Closer: Inclusion and Exclusion of Roma in Present-day Romanian Society, edited by Gábor Fleck and Cosima Rughiniș, 153-175. București: Human Dynamics.

Harry, Beth and Janette K. Klingner. 2006. Why Are so Many Minority Students in Special Education?: Understanding Race $\mathcal{E}$ Disability in Schools. New York: Teachers College Press.

Liga Pro Europa. 2006. Discriminarea Rasială în Județele Arad, Cluj, Harghita, Sibiu Şi Timiş. Noua Revistă de Drepturile Omului (3): 81125.

National Research Council (U.S.). 2002. Minority Students in Special and Gifted Education. Washington, D.C: National Academy Press.

Open Society Institute. 2005. Rights of People with Intellectual Disabilities Access to Education and Employment: Romania. Monitoring Report. București.

Open Society Institute. 2007. Equal Access to Quality Education for Roma. Monitoring Reports on Bulgaria, Hungary, Romania, and Serbia.

Open Society Institute. 2010. Roma Children in 'special Education' in Serbia: Overrepresentation, Underachievement, and Impact on Life. Research on Schools and Classes for Children with Developmental Difficulties. Budapest: Q.E.D. Publishing.

Oswald, Donald P., Martha J. Coutinho and Al M. Best. 2002. Community and School Predictors of Overrepresentation of Minority Children in Special Education. In Racial Inequity in Special Education, edited by Gary Orfield and Daniel J. Losen. Cambridge, MA: Harvard Education Press.

Roma Education Fund. 2007. Evoluția Educației Romilor în România. Evaluarea Țării și Direcțiile de Acțiune Strategice ale Fondului de Educație Pentru Romi. Roma Education Fund,

http://www.romaeducationfund.hu/sites/default/files/publication s/web_romania_report_romanian.pdf.

Shapiro, Thomas M. 2005. The Hidden Cost of Being African American: How Wealth Perpetuates Inequality. Oxford: Oxford University Press. 
State Agency for Child Protection. 2005. Right to Education for Children with Special Educational Needs. Newsletter of the SACP (2): 54.

Vincze, Enikő and Hajnalka Harbula. 2011. Strategii Identitare și Educație Şcolară. Raport de Cercetare Despre Accesul Copiilor Romi la Şcoală. ClujNapoca: Editura Fundatiei pentru Studii Europene. 